\title{
MODERN LANDFILLS AS POTENTIAL FEED BACK PROCESSES TO COUNTERACT GLOBAL WARMING
}

\author{
Torleif Bramryd \\ Michael Johansson \\ Dept of Environmental Strategy, University of Lund, Campus Helsingborg, PO \\ Box 882, SE- 25108 Helsingborg, SWEDEN.
}

\begin{abstract}
Provided that produced biogas is effectively collected, landfills are important sinks for organic carbon compensating for emissions of $\mathrm{CO} 2$ from burning of fossil fuels. Sequestrating of long-lived organic carbon in the landfill itself is the most pronounced factor, but also other processes during landfill management will increase the capture and binding of CO2.. Compost produced in connection to the landfills and applied as soil improvement, is another important sink for organic carbon. The landfills in the World have been estimated to accumulate around $100 \times 10^{6}$ metric tons of C. Normally about 25-40 percent of the total carbon content in the waste can be converted into biogas in traditional landfills. During landfilling most of the organic carbon in fossil derived products, like plastics, synthetic rubber, textiles and other synthetic materials, As these products take part in the methane gas production, the landfill gas (biogas) can be regarded as a true biofuel. In contrast to incineration, high moisture content in the waste will not decrease the yield of energy per ton of waste. In a reactor landfill treating approximately 100000 tons of waste per year, a longlived organic fraction corresponding to about 45000 metric tons of carbon dioxide is longterm accumulated each year. This compensates for the annual carbon dioxide emissions from about 15000 - 20000 cars, provided that each one runs $15000 \mathrm{~km}$ per year with fossil fuel. The technique for effective collection of landfill gas, and new techniques to upgrade and liquefy the biogas, have decreased the risk for emissions to the atmosphere. Modern bioreactor landfills have been estimated to have less than $10 \%$ diffuse biogas emissions to the atmosphere. Also in Sweden (Helsingborg), plants are built to convert landfill gas to upgraded, liquefied motor fuel. This will lead to strongly reduced diffuse emissions of landfill gas to the atmosphere. The utilization of leachates as forest fertilizer results in an improved biomass production and increased accumulation of soil organic matter. Increased tree and field layer productivity also means that the potential for water evaporation (eg. evapotranspiration) increase, reducing the costs for waste-water treatment or the risk for diffuse ground water pollution. Also in the mineral soil, increased long-lived fractions of humus normally are found. This should be added to the carbon accumulating effect of the landfill itself, where long-lived organic matter, mainly derived from lignin and from fossil fractions as plastics and synthetic textiles is long-term accumulated. In this respect the landfill system has similar effects compared to natural peatlands and lake and sea sediments, If produced biogas is collected effectively, the landfill thus can be an important factor to counteract the "green-house effect" and climate change.
\end{abstract}

\section{KEYWORDS}

Reactor landfill, bioreactor cell, biogas, climate change, $\mathrm{CO} 2$, carbon sink, carbon sequestrating, leachate,

https://doi.org/10.15626/Eco-Tech.2010.084 


\section{INTRODUCTION}

Since the industrialization started in the 1860-ies, the atmospheric $\mathrm{CO}_{2}$ concentration has increased rapidly, almost with $100 \mathrm{ppm}$, mainly due to human activities. The atmospheric $\mathrm{CO}_{2}$ concentration today has reached a value of approximately $380 \mathrm{ppm}$. The natural range of carbon dioxide concentrations over the last 650000 years is about 180-300 ppm, and thus the present concentration far exceeds these values. Over the period 1995-2005 the average growth-rate of the atmospheric carbon dioxide concentrations was about $1,9 \mathrm{ppm}$ per year on an average. (IPCC, 2007).

Natural ecological processes have insufficient capacity to balance the anthropogenic emissions of carbon dioxide. Thus it is of great importance to establish carbon-accumulating processes in the urban society. Accumulation of organic carbon in long-lived organic matter in the urban society, like in buildings, libraries, a.s.o. is also a process that might delay the release of $\mathrm{CO}_{2}$ to the atmosphere (Bramryd 1982, 1983). It was estimated that this accumulation in long lived products amounted to about $2.10 \times 10^{6} \mathrm{~g} \mathrm{C}$ per capita in industrialized countries and about $0.15 \times 10^{6} \mathrm{~g} \mathrm{C}$ per capita in less industrialized countries, resulting in a total sink of carbon in human society of over $3500 \times 10^{12} \mathrm{~g}$ organic carbon (Bramryd 1982).

Landfilling of organic matter withdraws organic carbon for long-term accumulation and sequestration in the landfill. Properly managed, landfills thus can be important sinks for organic carbon, compensating for emissions of $\mathrm{CO}_{2}$ from burning of fossil fuels. Landfills thus can be regarded as the anthropogenic counterpart to natural peatlands and lake sediments, i.e. ecosystems with a capacity to accumulate organic carbon, which thus can balance the increased atmospheric concentrations of $\mathrm{CO}_{2}$.

According to experiments with landfill bioreactor cells the diffuse emissions of biogas can be kept at a very low level. Experiments from biocell-reactors in several landfill sites in Sweden showed that the uncontrolled biogas emissions to the atmosphere were under $10 \%$ (Lagerkvist 1997). Thus with modern reactor landfilling the negative effects on climate from methane gas emissions can be controlled, leaving the positive effects of landfills as carbon sinks in focus.

Carbon in fossil derived products, like plastics and other synthetic materials, during landfilling will be brought back to long-term accumulation. As these products only to a very small extent take part in the methane gas production, the landfill gas (biogas) can be regarded as a true bio fuel (Binder and Bramryd, 2001). The long-lived organic material left in the fermentation residue in the landfill can, except from plastics, to a large extent can be derived from lignin compounds in the waste. Lignin compounds also make up for a major part of the litter fractions creating humus under aerobic conditions. Thus the organic fraction contributing to the methane formation in an anaerobic landfill or landfill reactor cell is normally short-lived, also in a natural aerobic environment, and therefore has a short turnover time. According to Barlaz et al. (1989), about 91 percent of the produced methane gas can be derived from cellulose and hemi-cellulose compounds. The reactor-cell fermentation technique thus very well conforms to the natural $\mathrm{CO}_{2}$ cycle. If the waste had been incinerated, most of the organic carbon would have been emitted as $\mathrm{CO}_{2}$, including carbon derived from fossil material. Due to high moisture content in municipal solid waste, energy will be consumed and $\mathrm{CO}_{2}$ produced for the evaporation of water. This contributes to the negative effects of waste incineration on the atmospheric carbon balance.

According to environmental and climate objectives set by the European Union, called 20/20/20, the carbon dioxide emissions in the EU must be reduced with $20 \%$ until 2020 , 
energy consumption must be decreased with $20 \%$ until 2020 and $20 \%$ of energy production must come from renewable sources until 2020. Biogas is a carbon neutral fuel, and the positive environmental impacts associated with the use of liquid biogas and biogas from reactor landfills, bioreactor cells and biogas reactors are perceived as great. With a modern bioreactor technique a major part of the biogas is collected in a reliable extraction system. On the other hand, if methane would have been allowed to escape to the atmosphere it could act as a severe greenhouse gas. However, modern research has shown, that the emissions from landfills are at much lower rates than earlier expected, mainly due to methane oxidizing bacteria in the surface cover layer of the landfill. Thus, even if there are no biogas collection systems, the amounts of produced methane in the landfill is reduced by approximately a factor 10 in the surface layer, before it escapes to the atmosphere.

\section{THE REACTOR LANDFILL AS A SINK OF ORGANIC CARBON}

The turn-over rate for organic matter differs largely between different types of landfills in the World. However a rough estimate of the annual accumulation of organic carbon in the World's landfills in the $1980^{\prime}$ 's indicated an accumulation of around $100 \times 10^{6}$ metric tons of C (Bramryd, 1982, 1983). However due to increased material recovery and increased incineration the present figure is probably somewhat lower, in spite of increased waste volumes. The size of the long-term accumulated fraction depends on the conditions for decomposition in the landfill. Estimates by Bogner and Spokas $(1993,1995)$ indicate that the fraction left for long-term accumulation in the World's landfills amounts to approximately 30 x $10^{12} \mathrm{~g} \mathrm{C}$ per year.

In Sweden, the total annual amount of mixed municipal and industrial waste that was landfilled before the ban on landfilling of organic matter was introduced in 2002 could be estimated to around $3 \times 10^{6}$ metric tons (SOU, 1996), corresponding to approximately $0.75 \mathrm{x}$ $10^{12} \mathrm{~g} \mathrm{C}$. Of this fraction about $0.40 \times 10^{12} \mathrm{~g}$ organic carbon can be regarded as resistant to degradation under normal landfill conditions. At the same time about $2 \times 10^{6}$ tons of waste was incinerated each year in Sweden, resulting in a release of about $0.50 \times 10^{12} \mathrm{~g} \mathrm{C}$. A fraction of about $0.30 \times 10^{12} \mathrm{~g} \mathrm{C}$ would have been more or less long-term accumulated if this amount of waste instead would have been landfilled or treated in landfill reactor cells. Today most of this long-lived carbon fraction instead is rapidly released to the atmosphere through incineration.

Investigations with landfill gas recovery and reactor cell fermentation have shown that approximately $150-200 \mathrm{~m}^{3}$ of biogas, with $50-55 \%$ methane gas concentration, can be extracted per ton treated waste with the first generation of a reactor cell fermentation technique. With $25 \%$ organic carbon per ton household and light industrial waste, and with a total carbon content of $500 \mathrm{~g} \mathrm{C}$ per $\mathrm{m}^{3}$ of biogas, this would mean that around $130 \times 10^{3} \mathrm{~g} \mathrm{C}$ per ton originally landfilled waste should remain in the landfill after approximately 15-20 years. Of this amount lignin contributes to approximately $40-50 \times 10^{3} \mathrm{~g} \mathrm{C}$ and plastics to about $20-30 \times 10^{3} \mathrm{~g} \mathrm{C}$. The remaining fraction, about $40-50 \times 10^{3} \mathrm{~g}$ could theoretically be converted to biogas after improving and optimizing the fermentation technique in e.g. landfill reactor-cells (biocells). The amount of total organic carbon discharged from landfill reactorcells through the leachates is small in comparison to the losses through the biogas, around 3-6 \% (Åkesson, 1997). Accordingly, approximately $70-90 \times 10^{3} \mathrm{~g}$ organic carbon per ton 
household waste would remain in the fermentation residue after advanced fermentation in landfill bioreactors, compared to about $130 \times 10^{3} \mathrm{~g} \mathrm{C}$ with the present technique for optimized biogas production. In a normal well-managed landfill with biogas extraction probably around $150 \times 10^{3} \mathrm{~g} \mathrm{C}$ is long term accumulated per ton landfilled waste. Household waste normally contains approximately $23-25 \%$ organic carbon, while industrial waste, with lower water content and normally a higher proportion of paper, wood and plastics, contains somewhat higher proportions of organic carbon. Plastics and rubber are rather unaffected by biological degradation and is left in the landfill. Under anaerobic conditions also lignin is resistant to degradation and will remain in the fermentation residue.

The estimates above indicate that around $60 \%$ of the organic carbon in the solid waste remain in the fermentation residue after normal landfilling, while about 30-50\% of the original carbon content would remain after optimized landfill reactor-cell (biocell) treatment. These estimates are somewhat lower compared to some earlier figures based on landfill fermentation studies, e.g. (Barlaz et al 1989; Cossu et al 1991; Bogner and Spokas 1993), which range from $60-75 \%$ for the remaining carbon fraction.

An average sized landfill bioreactor landfill in Sweden annually can be assumed to treat about 100000 ton residual municipal waste. This amount of waste corresponds to approximately 25000 ton organic carbon, or a fraction of approximately $15000 \times 10^{6} \mathrm{~g} \mathrm{C}$ each year which will be included in a long-lived fraction. This corresponds to about 45000 tons of carbon dioxide. The losses of organic carbon through the leachates only amount to a minor fraction. The long-lived carbon fraction accumulated in the fermentation residue thus corresponds to the total amount of carbon emitted per year from $12000-15000$ cars per year, running approximately $15000 \mathrm{~km}$ per year and emitting approximately $212 \mathrm{~g} \mathrm{CO}_{2}$ per $\mathrm{km}$. In addition to the accumulation of organic carbon resistant to mineralization, landfilling or treatment in reactor cells, also means an increasing amount of organic matter, which in spite of microbial degradation will be accumulated during a few years. Thus the positive effects on the carbon balance are not only related to the most long-lived fractions with fossil origin, which finally will be stored for a very long period of time.

With another comparison, Bramryd and Binder (2001) has calculated that the deposition of organic matter in a medium sized controlled landfill (100 000 tons per year) equals the total amount of carbon in approximately 65 hectares of grown-up spruce forest, or approximately 45 hectares of deciduous forest. It is of great importance to create carbon sinks in the urban society, as the natural $\mathrm{CO}_{2}$ balancing processes are insufficient to compensate for the increasing emissions of carbon dioxide.

The organic matter resulting from composting or reactor fermentation can be used as soil improvement in agriculture, horticulture or forestry, where a fraction of the organic matter is rather resistant to degradation. Thus this will lead to an increased pool of soil organic carbon. The use of such compost or bio-residue in sandy soils, or in soils with high clay content, will also increase plant production and result in more organic carbon accumulated in the standing crop.

\section{LIQUEFIED BIOGAS}

Biogas extracted from waste treatment is an important renewable fuel, which can substitute for fossil fuels, reducing the emissions of fossil $\mathrm{CO}_{2}$ to the atmosphere. In 2008, landfill gas extraction in Sweden amounted to $375 \mathrm{GWh}$. Mainly due to the lack of available technology 
for upgrading landfill gas, and as upgrading costs are relatively high, landfill gas has so far only been used for heat and electricity production. In recent years however, there has been an increased interest to upgrade landfill gas to vehicle fuel. This has been stimulated even more by the fact that there is a rapidly increasing interest among public transportation companies for biogas utilization in busses and taxis. This has been added to the escalating interest among companies and private people to use biogas as a fuel for transportation, and has resulted in a severy shortage of available biogas suitable as motor fuel. Therefore there will be a very positive market for upgrading landfill gas to motor fuel. However due to logistic problems threre are sometimes problems to supply biogas to the relevant bus depots and tanking stations. Liquid Biogas then is an interesting alternative, and more efficient for transportation compared to in gas form, and it is also easier to store. Today the production of liquid biogas is energy-consuming, but it is has great environmental benefits. Liquid Biogas may replace diesel, and has similar efficiency, reliability and maintenance costs as this fuel. Since biogas and liquid biogas are defined as renewable fuels they will also have a potential to meet the policy framework for reduction of climate change. They have a potential to supply domestic and local production (creates local jobs), regional development and the phasing out of fossil fuels.

The energy density of Liquid Biogas is three times as high compared to compressed biogas. In order to maintain the biogas in a liquid form it must be frozen to -160 degrees $\mathrm{C}$, which is not possible to use for tanking of cars. This means that biogas should be converted into ordinary compressed gas at gas service stations, before refueling of cars can be done (New Technology, 2009). One of the advantages of liquid biogas is that transportation to the gas stations will be more efficient.

In Helsingborg, South Sweden, a liquid-biogas plant under construction will have a production of biogas corresponding to 15 million liters of liquid biogas per year (equivalent to about $60 \mathrm{GWh}$ ) for at least 20 years with mainly the already landfilled waste as raw material. It would present a fossil carbon dioxide reduction by 40 000 metric tones of $\mathrm{CO}_{2}$ per year compared to conventional diesel (NSR, 2009).

Liquid biogas is nothing new or revolutionary and the technique has been used for many years in the oil fields. According to Öhman (2009), however, it has previously been difficult to condense biogas due to varying composition of the biogas. The future of liquid biogas is positive, especially in the regions where there under the current situation is no existing natural gas grid available. For the transport of liquid biogas conventional LNG trucks (Liquid Natural Gas) can be used. Such a truck can carry six times the amount of biogas compared to a vehicle with CBG (Compressed biogas) (Öhman, 2009). The main barrier to use landfill gas as a vehicle fuel is to achieve a cost-effective separation of nitrogen. Because of similarities in the physical properties of methane and nitrogen, methane losses during upgrading of landfill gas are relatively high and amounts to $16-23 \%$, depending on technology used. However losses from upgrading of methane can be used for energy production, with the addition of fuel (Benjaminsson et al 2010).

\section{LEACHATES AS FERTILIZER TO IMPROVE CARBON ACCUMULATION}

Landfill organic carbon, which is resistant to anaerobic decay, e.g. derived from the lignin fraction of the waste, helps to retain water in the fermentation residue and maintain high moisture content. This will provide for a reliable long-term storage in the fermentation residue of heavy metals bound up as sulphides, which are insoluble under anoxic conditions. Thus, in the leachate mainly metals with a low atomic weight, as nutrients like sodium, potassium, magnesium and calcium, will occur together with nitrogen fractions. Thus, longlived organic matter from landfilling of e.g. paper and wood products will act as a stabilizer for the landfill and immobilize toxic elements in a rather stable fermentation residue, which is left in the landfill. This chemical separation will open possibilities for nutrient separation and recovery through the utilization of the leachates as fertilizer in e.g. energy forests situated 
within the controlled landfill area. This will create a standing biomass and soil organic matter acting as an additional pool of organic matter linked to the landfill or bioreactor cell facility.

Ashes remaining after burning of the produced biomass, containing most of the nutrients, will be used as a fertilizer or vitalizing agent in normal forestry. This in turn opens the possibilities to use a larger proportion of the logging residues from forests as a renewable fuel, decreasing the emissions of fossil $\mathrm{CO}_{2}$ even more. This circulation of nutrients will not be possible after waste incineration, as in this case the nutrients cannot easily be separated from toxic heavy metals, and the total amount of mixed ashes have to be long-term stored in landfills. Ashes from waste incineration mostly are classified as toxic waste.

In an experiment at Telge $\mathrm{AB}$ waste treatment facility in Södertälje, south of Stockholm, approximately $7000 \mathrm{~m} 3$ of leachates was irrigated over an approximately $150 \times 50 \mathrm{~m}$ wide forest plantation (15-20 years old), dominated by birch (Betula pubescens), rowan (Sorbus acuparia), willow (Salix caprea), spruce (Picea abies) and pine (Pinus sylvestris). The irrigation continued for 5 years during the period mid-May to early October (about 175 days) each year (Bramryd et al 2009).

The content of total organic carbon (C) increased mainly in the humus layer after irrigation, which is an effect of a larger litter production from a gradually increasing biomass. Even a slight increase can be measured of the carbon content in the uppermost mineral soil layer, which depends on leaching of resistant humic substances. This means that leachate fertilization leads to an increased amount of organic carbon that can be accumulated in the soil, which is positive from a carbon balance perspective. Planting of an energy forest within a landfill area will also immobilize $\mathrm{CO}_{2}$ in standing biomass. In such a forest plantation, supplied by nutrients extracted from the waste in connection to utilization of leachates for irrigation, organic matter corresponding to approximately 10 tons of carbon can be stored in plant biomass per hectare each time unit, in spite of a short turn-over time for the produced biomass (Bramryd et al 2010).

Nutrients from the applied leachates contribute with macro and micro nutrients to the trees, while dissolved organic matter in the leachates is partly decomposed by the soil organisms. An optimal growth is necessary to maximise the nutrient uptake. Areas of the plantation irrigated with treated leachate showed a visibly higher production and improved tree vitality, compared to reference areas. This was the situation for the deciduous trees as well as for spruce and pine. Because the nitrogen levels in the leachate was reduced during a preparatory purification step in a reed beds, the nutritional balance in the leachates was favourable also for coniferous trees, with a beneficial balance between the input of nitrogen, phosphorus, potassium and magnesium. The expected risk of nitrogen over-saturation was not detected, and the growth and vitality are rather strongly stimulated by the leachate irrigation. This implies a positive impact from both a forest economic point of view and from the perspective of the forest to function as a sink for organic carbon. Both the tree and bush layers, as well as the field layer vegetation, were dense in the irrigated areas. This indicates an optimal and balanced nutrient supply, and that the evaporation potential of leachates thus is good in the ecosystem. The fact that the irrigated part of the forest shows a much larger standing biomass means that more organic carbon is accumulated here than in the reference areas. Thus, forest irrigation means that a carbon sink is created, which e.g. can compensate for anthropogenic $\mathrm{CO}_{2}$ emissions, e.g. from traffic. The technique thus gives an additional environmental effect than just to clean the leachate and prevent the release of eutrophic substances into water 
systems. This increased amount of organic carbon bound up in a full scale forest plantation, irrigated with leachates, can be comparable with the annual $\mathrm{CO}_{2}$ emissions from up to 3000 5000 cars (Bramryd et al 2009).

\section{CONCLUSIONS}

1. Landfilling of the residuals from fermentation of mixed municipal solid waste, with a high concentration of organic matter, will produce a sink for organic carbon and will counteract increased atmospheric concentrations of $\mathrm{CO}_{2}$. If diffuse emissions of methane are controlled and minimized, landfilling of organic matter has a positive effect also as a moderator of "global warming".

2. A middle-sized landfill system, receiving approximately 100000 tons of waste per year, and with leachate irrigation in a forest plantation, can compensate for the annual $\mathrm{CO}_{2}$ emissions from around 15- 20000 cars.

3. Landfilling is the recommended route for disposal of plastics, synthetic rubber and other products with a fossil origin, which no longer can be recycled through material recovery. Landfilling will return the carbon with fossil origin to long-term storage.

4. Fermentation of residual wastes in Bioreactor cells or Reactor landfills should be regarded as a biological pre-treatment technique, and the mostly biologically inert residues can be retained in a landfill after the concentrated fermentation phase, without the risk for emissions of green-house gases.

5. Improved biomass production and accumulation of soil organic matter after irrigation with leachates to forest plantations, within the restricted landfill area, increase the effect of landfills as carbon sinks, and alone can compensate for anthropogenic $\mathrm{CO}_{2}$ emissions comparable to the annual $\mathrm{CO}_{2}$ release from up to 3000 - 5000 cars.

6. Liquidizing biogas is a way to improve the possibilities for efficient use as motor fuel, improving the transport efficiency.

\section{REFERENCES}

[1] Barlaz M. A., Ham R. K., and Schaefer D. M. (1989) Mass-balance analysis of anaerobically decomposed refuse. - J. Environmental Engineering Division ASCE 115, 1088-1102.

[2] Benjaminsson J., Johansson N., and Karlsvärd J. 2010. Deponigas som fordonsbränsle. Rapport SGC 214. Svenskt Gastekniskt Centrum, 59 pp.

[3] Binder M. and Bramryd T. 2001. Comparison between former and present landfill techniques in respect to impacts on the environment. Water, Air \& Soil Pollution 129, 289-303.

[4] Bogner J. and Spokas K. (1993) Landfill $\mathrm{CH}_{4}$ : Rates, fates, and role in global carbon cycle. - Chemosphere 26, 369-386. 
[5] Bogner J. and Spokas K. (1995) Carbon storage in landfills. In: Soils and Global Change. Advances in soil science. (Lal, Kimble, Levine and Stewart eds.). Chapter $\underline{5}$. , p 67-80. Lewis Publishers, Boca Raton, London, Tokyo.

[6] Bramryd T. (1982) Fluxes and accumulation of organic carbon in urban ecosystems on a global scale. - In Urban Ecology (Bornkamm, Lee and Seaward, eds.), Blackwell Scientific Publications, Oxford, 3-12.

[7] Bramryd T. (1983) Human impact on the biogeochemical cycling of carbon between terrestrial ecosystems and the atmosphere. Environmental Biogeochemistry. Ecol. Bull. (Stockholm) 35, 301-313.

[8] Bramryd T. and Binder M. 2001. Landfill bioreactor cells as anaerobic filters for controlled extraction of bio-energy and nutrients from municipal solid wastes. The Environmentalist 21, 297-303.

[9] Bramryd T, Johansson M, Nielsen T, Tham G, Renman G, Bengtsson B-E, Stiernström S, and Breitholtz M 2009. Treatment of landfill leachates in a combined wetland and forest irrigation system for increased biomass production - A part of the strategy to regard landfills as a carbon sink. Sardinia 09. Proc. Twelfth International Waste Management and Landfill Symposium, S. Margherita di Pula (Cagliari), Sardinia, Italy, 5-9 Oct 2009.

[10] Cossu R., Stegmann R. and Acaia C. (1991) Treatment of vegetation water on layers of MSW organic fractions. In: Sardinia'91. Third International Landfill Symposium, pp 1461-1476, CISA (Environmental Sanitary Engineering Center), University of Cagliari, Sardinia.

[11] IPCC (2007) Climate Change 2007: The Physical Science Basis. Summary for Policymakers. Contribution of Working Group I to the Fourth Assessment Report of the Intergovernmental Panel on Climate Change. IPCC Secretariate, Geneva, Switzerland, $21 \mathrm{pp}$.

[12] NSR, (2009). NSR långt över miljömål. www.nsr.se. The site visited 2010-0203.

[13] Ny teknik (2009). www.nyteknik.se. Skåne först med Volvos flytande biogas. The site visited 2009-12.20.

[14] SOU (1996) Skatt på avfall. Slutbetänkande av Deponiskatteutredningen. Statens Offentliga utredningar, 1996:139. Finansdepartementet, Stockholm, 459 pp.

[15] Åkesson M. (1997) Landfill ecosystem nutrition. - In: Biogas generation in landfills - equilibrium, rates and yields. Doctoral Thesis Dept. of Water Resources Engineering, Lund University, Report 1018.

[16] Öhman, A (2009). Kryoteknisk behandlad biogas. - En utvärdering med utgångspunkt i Stockholm. Examensarbete, Avdelningen för Energihushållning, Institutionen för Energivetenskaper, Lunds Tekniska Högskola, Lunds Universitet. 